\title{
Purification and Characterization of a Corynebacterium ulcerans Bacteriocin (Ulceracin 378)
}

\author{
By KHACHIK ABREHEM*† AND IRAJ ZAMIRI \\ Diphtheria Reference Laboratory, Department of Medical Microbiology, \\ Welsh National School of Medicine, Cardiff CF4 4XN, UK
}

(Received 3 October 1984; revised 22 November 1984)

Corynebacterium ulcerans strain 378 produces a bacteriocin (ulceracin 378 ) and a toxin when grown on semi-solid medium. Ulceracin 378 was purified 360 -fold by dialysis and chromatography on DEAE-cellulose and Sephadex G-200. On the basis of Ultrogel AcA22 gel filtration its molecular weight was about 900000 . It could be dissociated by 2 -mercaptoethanol and sodium dodecyl sulphate into smaller subunits of 25000 . The bactericidal activity was associated with this subunit which contained no carbohydrate or lipid. Ulceracin 378 was thermostable and stable over a wide $\mathrm{pH}$ range. Purified ulceracin 378 did not have a toxic effect (lethal) on guinea-pigs and rabbits and was immunologically distinct from the toxin.

\section{INTRODUCTION}

A previous paper (Abrehem \& Zamiri, 1983) described the production of a bacteriocin named ulceracin 378 obtained from a toxinogenic strain of Corynebacterium ulcerans. Ulceracin 378 was not found in broth cultures and could not be extracted from the organisms by various solvents and salt solutions. Its synthesis was not inducible by UV irradiation or mitomycin C treatments. However, ulceracin 378 could be extracted from semi-solid medium on which the organisms had grown. Ulceracin 378 was active against all of the $C$. ulcerans strains and related species tested, without being autoinhibitory. Its synthesis did not seem to be under the control of a plasmid nor was it phage-related. Other studies in this laboratory have revealed that this same strain of $C$. ulcerans when grown under conditions identical to those used for ulceracin production, also produced a toxin (Abrehem \& Zamiri, 1980). The toxin was purified to a high degree of homogeneity; it lacked detectable carbohydrate or lipid and had a single polypeptide chain of molecular weight $14000 \pm 1000$. The toxin showed no bactericidal activity but was lethal to guinea-pigs and rabbits and could be totally neutralized by diphtheria antitoxin.

This paper deals with the purification and characterization of ulceracin 378 and shows that it is distinct from the toxin produced under similar conditions.

\section{METHODS}

Micro-organisms. Bacteriocinogenic and toxinogenic Corynebacterium ulcerans strain 378 and the strain susceptible to ulceracin 378, Corynebacterium diphtheriae var. mitis 5104 were from the Diphtheria Reference Laboratory, Welsh National School of Medicine, Cardiff, UK.

Chemicals. Sudan Black B, Oil Red O, SDS, all enzymes and proteins were from Sigma; Sephadex G-200 and Blue Dextran 2000 were from Pharmacia; DEAE-cellulose DE-52 was from Whatman; Ultrogel AcA22 and AcA34 were from LKB; acrylamide $N, N, N^{\prime}, N^{\prime}$-tetramethylenediamine and methylenebisacrylamide were from Koch-Light; Bromophenol blue was from Hopkin \& Williams; Coomassie brilliant blue was from Gurr; and 2mercaptoethanol was from BDH. All other chemicals used were of analytical grade.

† Present address: Bio-Medical Science Laboratories, 4250 Wilshire Boulevard, Los Angeles, California 90010 , USA. 
Isolation and assay of ulceracin 378. The media, isolation and assay procedures used were as described by Abrehem \& Zamiri (1983). Serum substitute broth (SSB) contained $20 \mathrm{~g}$ Proteose peptone (Difco), $3 \mathrm{~g}$ Casamino acids (Difco), $4.8 \mathrm{~g}$ sodium chloride, $1 \mathrm{ml}$ glycerol (BDH) and $1.2 \mathrm{ml}$ Tween 80 (BDH) per $1 \cdot 2$ litres distilled water. Serum substitute agar (SSA) was SSB solidified by the addition of $12 \mathrm{~g}$ agar per 1.2 litres and soft SSA was solidified by the addition of $6 \mathrm{~g}$ agar per 1.2 litres of SSB. Soft SSA without Tween 80 was termed SSA-T. All media were brought to $\mathrm{pH} 7.8$ and sterilized at $120^{\circ} \mathrm{C}$ for $20 \mathrm{~min}$.

Molecular weight estimation. A column $(2.2 \times 45 \mathrm{~cm})$ of Ultrogel AcA22 equilibrated with $50 \mathrm{mM}-\mathrm{Tris} / \mathrm{HCl}$ buffer (pH 7.8) at $4{ }^{\circ} \mathrm{C}$ was calibrated with human serum proteins. The flow rate was $12 \mathrm{ml} \mathrm{h}^{-1}$ and fractions of $3.5 \mathrm{ml}$ were collected and estimated for protein content by absorption at $280 \mathrm{~nm}$. The elution volume $\left(V_{\mathrm{e}}\right)$ of $\alpha_{2}-$ macroglobulin, IgM, IgG and albumin were determined by rocket immunoelectrophoresis of fractions and these proteins served as molecular weight markers. Under identical conditions $3 \mathrm{ml}$ ulceracin $\left(128 \mathrm{U} \mathrm{ml}^{-1}\right) \mathrm{was}^{-}$ fractionated and all fractions were assayed for protein content and ulceracin activity. Blue Dextran was used to estimate the void volume $\left(V_{\mathrm{o}}\right)$. The molecular weight of ulceracin 378 was estimated from the graph of $V_{\mathrm{e}} / V_{\mathrm{o}}$ versus molecular weights of the protein standards.

Purification of ulceracin. The crude ulceracin preparation extracted by freezing and thawing was concentrated and partially purified by ion-exchange chromatography as follows. Crude ulceracin $(150 \mathrm{ml})$ with an activity of $16 \mathrm{U} \mathrm{ml}^{-1}$ was dialysed against 3 litres $50 \mathrm{mM}$-Tris $/ \mathrm{HCl}$ buffer $(\mathrm{pH} \mathrm{7.8)}$ containing $0.02 \%(\mathrm{w} / \mathrm{v})$ sodium azide in cellophane tubing at $4{ }^{\circ} \mathrm{C}$ for $10 \mathrm{~h}$. The retentate was clarified by centrifugation at $5000 \mathrm{~g}$ for $20 \mathrm{~min}$ followed by membrane filtration $(0.45 \mu \mathrm{m}$ pore size). The clear filtrate was applied to a DEAE-cellulose ion-exchange column $(10 \times 200 \mathrm{~mm})$, equilibrated with $50 \mathrm{~mm}$-Tris/HCl buffer $(\mathrm{pH} 7.8)$ containing $0.2 \%(\mathrm{w} / \mathrm{v})$ sodium azide. After $150 \mathrm{ml}$ of the ulceracin preparation had passed through the column, the column was washed with $40 \mathrm{ml}$ of the same buffer. The collected fractions were then assayed for protein content at $A_{280}$ and their ulceracin activity determined. Subsequently the adsorbed ulceracin was eluted with $50 \mathrm{mM}$ - Tris/HCl buffer $(\mathrm{pH} 7.8$ ) containing $1 \mathrm{M}$ sodium chloride and $0.02 \%$ sodium azide.

For further purification $2 \mathrm{ml}$ DEAE-cellulose-purified ulceracin $378\left(1024 \mathrm{U} \mathrm{ml}^{-1}\right)$ was applied to a Sephadex G-200 column $(2.5 \times 35 \mathrm{~cm})$ in $50 \mathrm{mM}$-Tris/ $\mathrm{HCl}$ buffer $(\mathrm{pH} \mathrm{7.8)}$. Fractions $(3 \mathrm{ml})$ were collected and assayed for ulceracin activity and UV absorption at $280 \mathrm{~nm}$. The flow rate was $14.4 \mathrm{ml} \mathrm{h}^{-1}$, and the void volume was determined with Blue Dextran 2000.

$S D S-P A G E$. This was done according to the methods described by Weber \& Osborn (1969). Gels (5\%) were prepared in gel buffer containing $0 \cdot 2 \%$ SDS. The gels used in this study contained $11 \cdot 1 \%(\mathrm{w} / \mathrm{v})$ acrylamide and $0.3 \%(\mathrm{w} / \mathrm{v})$ methylenebisacrylamide. Purified ulceracin was added to $0.01 \mathrm{M}$-phosphate buffer $(\mathrm{pH} 7 \cdot 0$ ), containing $0.1 \%$ SDS and $0.1 \% \beta$-mercaptoethanol and incubated at $35^{\circ} \mathrm{C}$ for $30 \mathrm{~min}$. Glycerol was added to the sample to increase the viscosity before $50-100 \mu$ l of the sample was carefully added at the top of each column, which measured $0.5 \times 8 \mathrm{~cm}$. Electrophoresis was done in a Shandon Scientific disc electrophoresis apparatus at room temperature and $6 \mathrm{~mA}$ was applied per gel for $3.5 \mathrm{~h}$. After electrophoresis the gels were stained for protein with Coomassie brilliant blue (Weber \& Osborn, 1969), for lipid by Oil Red O or Sudan Black B (Sargent \& George, 1975), and for carbohydrate by the periodic acid-Schiff reaction (Crowle, 1961). The ulceracin activity could be detected according to the method described by Jetten et al. (1972), in which the unstained gels were soaked for 18 to $24 \mathrm{~h}$ in $50 \mathrm{ml}$ Tris/ $\mathrm{HCl}$ buffer $\left(\mathrm{pH} \mathrm{7.8)}\right.$ at $4^{\circ} \mathrm{C}$ to remove SDS and 2-mercaptoethanol. They were then cut longitudinally and placed aseptically in a molten serum substitute agar plate $(30 \mathrm{ml})$ and overlaid with the indicator strain ( $4 \mathrm{ml}$ soft serum substitute agar without Tween 80 ) seeded with $0 \cdot 1 \mathrm{ml}$ indicator strain 5104 . The plates were incubated at $35^{\circ} \mathrm{C}$ for $18-24 \mathrm{~h}$. The relative position of the zone of inhibition could then be compared with the location of bands in stained gels which were run at the same time. By plotting the mobility of the marker proteins versus log (molecular weight), a standard curve was constructed.

Heat and $\mathrm{pH}$ treatment of ulceracin 378 . Ulceracin 378 in $50 \mathrm{~mm}-\mathrm{Tris} / \mathrm{HCl}$ buffer $(\mathrm{pH} 7.8)$ was held for $30 \mathrm{~min}$ at various temperatures $\left(0\right.$ to $\left.100^{\circ} \mathrm{C}\right)$. The precipitate was removed by centrifugation, the supernate was filtered through a $0.45 \mu \mathrm{m}$ (pore size) membrane filter and ulceracin activity was determined in the filtrate. Ulceracin 378 in the same buffer was incubated at various $\mathrm{pH}$ values $(2.0$ to 14.0$)$ for $60 \mathrm{~min}$ at room temperature. To exclude possible bactericidal effects of low or high $\mathrm{pH}$ values on the indicator strain, the $\mathrm{pH}$ of the supernate was readjusted with $1 \mathrm{M}-\mathrm{NaOH}$ or $\mathrm{HCl}$ to $\mathrm{pH} 7 \cdot 8$. The contents of each tube were adjusted to the same volume with $50 \mathrm{mM}-\mathrm{Tris} / \mathrm{HCl}$ buffer ( $\mathrm{pH} \mathrm{7.8)}$. The precipitate, if any, was removed by centrifugation and filtered through a $0.45 \mu \mathrm{m}$ (pore size) membrane filter and assayed for ulceracin activity.

Electron microscopy. One drop of purified ulceracin solution containing $0.1 \mathrm{mg}$ protein $\mathrm{ml}^{-1}$ in $50 \mathrm{mM}-\mathrm{Tris} / \mathrm{HCl}$ buffer ( $\mathrm{pH} 7.8)$ was mixed with one drop of uranyl acetate solution $(1 \%$, w/v) adjusted to $\mathrm{pH} 6.0$ on a clean glass slide. A drop of this mixture was applied to a specimen grid covered with a carbon-coated collodion film. The excess liquid was withdrawn with a wet filter paper and the specimen examined in a Philips EM 300 electron microscope operating at $80 \mathrm{kV}$ and an instrument magnification of 33000 .

Antiserum production. Antiserum against purified ulceracin 378 was produced by intradermal injection of 1 in 5 dilutions of ulceracin in saline, mixed with an equal amount of Freund's complete adjuvant (Difco). Each rabbit received a single dose of 10 injections each of $50 \mu \mathrm{l}(62 \mu \mathrm{g}$ protein) and was bled one month later. 
Rocket electrophoresis. Electrophoresis at pH 8.6 was carried out according to Laurell (1972).

Immunodiffiusion. Molten $1 \%$ agarose $(15 \mathrm{ml})$ in Tris or phosphate-buffered saline [PBS; potassium phosphate $0.15 \mathrm{M}, \mathrm{NaCl} 0.85 \%(\mathrm{w} / \mathrm{v}), \mathrm{pH} 7 \cdot 2$ ] was layered onto a glass slide $(10 \times 10 \mathrm{~cm})$. When it had solidified, $5 \mu 1$ holes were punched out at a distance of $2 \mathrm{~mm}$ and filled with antigen or antiserum. Plates were examined after $2 \mathrm{~d}$ at room temperature.

Immunogenicity. To test the anti-ulceracin serum for its neutralization capacity, a fixed amount of ulceracin was mixed with serial twofold dilutions of antiserum in PBS or Tris buffer and incubated at $35^{\circ} \mathrm{C}$ for $4 \mathrm{~h}$ and then at $4{ }^{\circ} \mathrm{C}$ overnight. From each dilution $25 \mu \mathrm{l}$ was spotted on a $3 \mathrm{ml}$ soft serum substitute agar without Tween 80 seeded with indicator cells. The plates were incubated at $35^{\circ} \mathrm{C}$ for $18 \mathrm{~h}$ and then at room temperature for $24 \mathrm{~h}$. The end point was considered as the highest dilution of serum which neutralized ulceracin activity and showed no inhibition of growth. A control of ulceracin preparation with an equal volume of Tris buffer was similarly treated.

\section{RESULTS}

Most of the ulceracin was eluted with the high salt buffer in a total volume of $2 \mathrm{ml}$. This represented a 75 -fold increase in concentration. In addition the specific activity was increased from 3.55 to $128 \mathrm{U}(\mathrm{mg} \text { protein })^{-1}$.

For further purification the active fractions were pooled and applied to a column of Sephadex G-200. Most of the activity was found in the fraction which eluted in the void volume of the column. A later fraction corresponding to the second major absorbance peak contained most of the coloured material with no bactericidal activity $(C$. ulcerans toxin is eluted in the second peak). Active fractions were pooled and gave a specific activity of $1280 \mathrm{U}$ (mg protein) ${ }^{-1}$ when compared to the initial specific activity (Table 1). This purification procedure has been repeated on five other occasions with highly reproducible results.

\section{Molecular weight determinations}

Gel filtration. On gel filtration through Ultrogel AcA22, ulceracin was eluted in a single peak near the void volume between the elution position of $\alpha_{2}$-macroglobulin and IgM. From the graph of $V_{\mathrm{e}} / V_{\mathrm{o}}$ versus molecular weight for the markers, a molecular weight for ulceracin of 900000 was found (Fig. 1).

$P A G E$. Purified ulceracin 378 was somewhat heterogeneous, as judged by SDS-PAGE (Fig. $3 a$ ). However, after elution from unstained gels the major band alone exhibited ulceracin activity and repeated electrophoresis under the same conditions gave a single band retaining bactericidal activity (Fig. $3 c$ ). The presence of only a single band in the ulceracin preparation is considered as evidence for its purity and molecular homogeneity (Fig. $3 b$ ). To determine the molecular weight, marker proteins were run in parallel. By plotting the mobility of the marker proteins versus log (molecular weight), a standard curve was constructed. From this curve the calculated molecular weight of the ulceracin subunit was 25000 ; similar values being found on three occasions (Fig. 2).

\section{Stability of ulceracin 378}

Highly purified ulceracin after lyophilization is a white powder freely soluble in water. Both concentrated and unconcentrated purified preparations in Tris/ $\mathrm{HCl}$ buffer $(\mathrm{pH} 7.8)$ retained full activity at $4{ }^{\circ} \mathrm{C}$ for one month but this decreased by half on storage at the same temperature for five months.

Table 1. Characteristics of ulceracin 378 at various stages of purification

$\begin{array}{lcccccc}\text { Purification step } & \begin{array}{c}\text { Vol. } \\ (\mathrm{ml})\end{array} & \begin{array}{c}\text { Activity } \\ \text { (total units) }\end{array} & \begin{array}{c}\text { Protein } \\ (\mathrm{mg})\end{array} & \begin{array}{c}\text { Sp. act. } \\ {\left[\mathrm{U}(\mathrm{mg} \text { protein })^{-1}\right]}\end{array} & \begin{array}{c}\text { Recovery } \\ (\%)\end{array} & \begin{array}{c}\text { Purification } \\ \text { factor }\end{array} \\ \text { preparation } & 150 & 2400 & 675 & 3.55 & 100 & 1 \\ \text { sis } & 150 & 2400 & 645 & 3.72 & 100 & 1 \cdot 05 \\ \text { entration by adsorption to } & & & & & & \\ \text { AE-cellulose } & 2 & 2048 & 16 & 128 & 85 \cdot 3 & 36.05 \\ \text { adex G-200 gel filtration } & 6 & 768 & 0.6 & 1280 & 32 & 360 \cdot 5\end{array}$




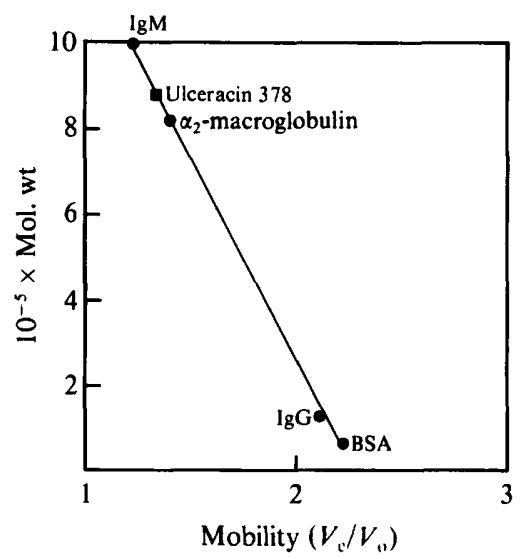

Fig. 1

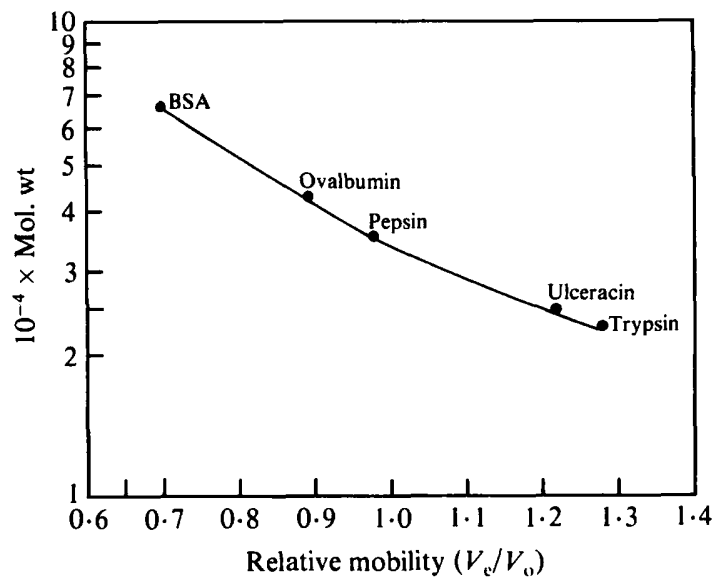

Fig. 2

Fig. 1. Determination of the molecular weight of ulceracin using a calibrated column of Ultrogel AcA22. To determine molecular weight, elution volume $\left(V_{e}\right)$ divided by void volume $\left(V_{0}\right)$ was plotted versus molecular weight of marker proteins.

Fig. 2. Determination of the molecular weight of the ulceracin subunit from SDS-PAGE ( $5 \%$ gel). The relative mobility of each marker protein was plotted versus $\log _{\mathrm{t} 0}$ (molecular weight).

(a)

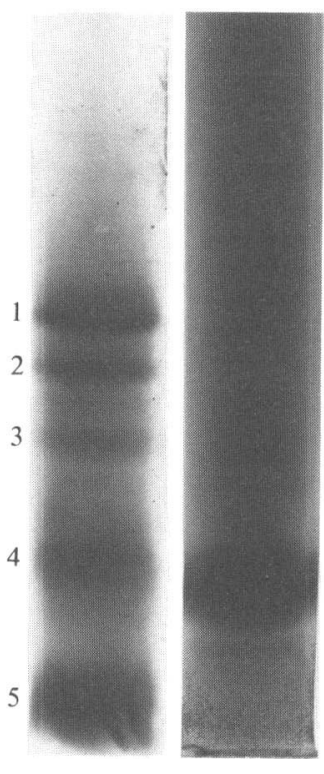

(b)

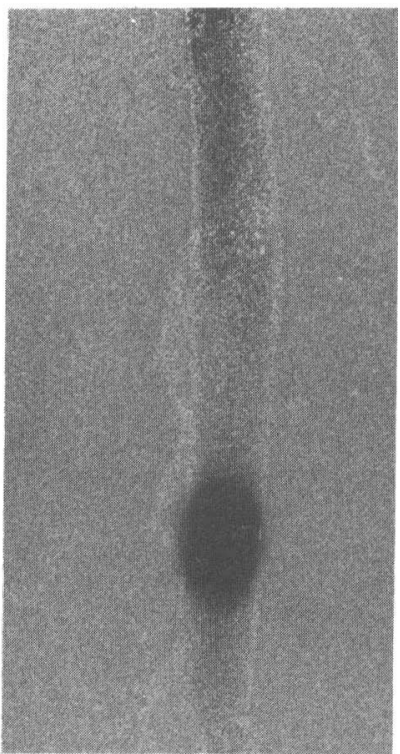

Fig. 3. SDS-PAGE of gel (a) ulceracin 378 purified by ion-exchange chromatography, prior to Sephadex G-200; gel $(b)$ the major band from $(a)$ re-electrophoresed, with $(a)$ and $(b)$ stained for protein with Coomassie brilliant blue; gel $(c)$ unstained gel as for $(b)$ showing corresponding band when tested for ulceracin activity. In gel $(a)$ five bands are illustrated, three minor bands $(1,2,3)$ and two major bands $(4,5)$. Band 4 represents ulceracin 378 and band 5 represents $C$. ulcerans 378 toxin. 


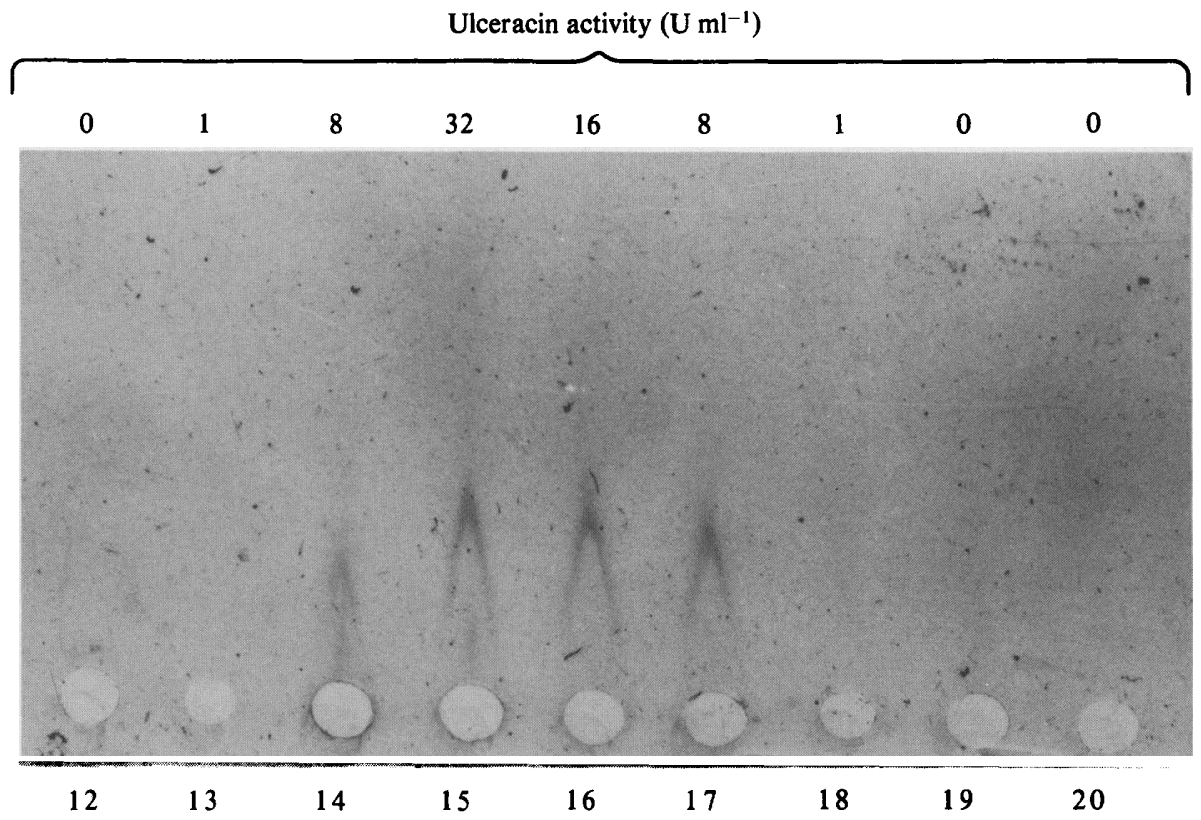

Fig. 4. Rocket immunoelectrophoresis of fractions (12-20) from Ultrogel AcA34. Height of the rockets (fractions 14-17) corresponded with amount of ulceracin activity. The main precipitation line obtained in immunodiffusion experiments coincided with the above activity.

Although crude ulceracin was inactivated after freeze-drying, purified ulceracin could be successfully freeze-dried in the presence of $1 \mathrm{mg}$ bovine serum albumin $\mathrm{ml}^{-1}$. Ulceracin activity was not affected by $2 \mathrm{M}-\mathrm{NaCl}, 0.05 \% \mathrm{NaN}_{3}, 10 \%$ glycerol, $50 \mathrm{mM}$-cysteine hydrochloride, $20 \mathrm{~mm}-\mathrm{MgSO}_{4}, 10 \mathrm{mM}-\mathrm{CaCl}_{2}$ and chloroform. Treatment of purified and partially purified ulceracin at $35^{\circ} \mathrm{C}$ for $45 \mathrm{~min}$ with 2 -mercaptoethanol $(0 \cdot 1 \%$, w/v)/SDS $(0 \cdot 1 \%$, w/v) decreased its activity by half.

Although ulceracin retained full activity within a pH range of 3 to 10 , it was inactivated by higher alkali values. This inactivation was pronounced at $\mathrm{pH} 14.0$ with at least $95 \%$ of the activity being destroyed. Ulceracin retained full activity after exposure to $70{ }^{\circ} \mathrm{C}$ for $30 \mathrm{~min} ; 50 \%$ of the activity was recovered at $80^{\circ} \mathrm{C}, 25 \%$ at $90{ }^{\circ} \mathrm{C}$ and only $12.5 \%$ at $100{ }^{\circ} \mathrm{C}$.

\section{Electron microscopy of ulceracin 378}

Purified ulceracin preparation ( $\times 362$-fold) containing $0.1 \mathrm{mg}$ protein $\mathrm{ml}^{-1}$ was mixed with uranyl acetate and examined under the electron microscope. Numerous irregularly shaped granules with diameters of $12-40 \mathrm{~nm}$ were observed. None of the micrographs at various magnifications revealed any structures resembling bacteriophages or their fragments.

\section{Immunogenicity}

An antiserum at a titre of $1 / 32$ was capable of neutralizing ulceracin activity. In immunodiffusion experiments the antiserum directed against ulceracin reacted with both highly purified and partially purified ulceracin and gave a precipitin line. With more highly purified and concentrated ulceracin a stronger precipitin line was obtained. To confirm that the precipitation reaction was directed against ulceracin, ulceracin 378 was fractionated by gel filtration (Ultrogel AcA34) and the fractions were tested for ulceracin activity and for reactivity against the antiserum by rocket immunoelectrophoresis. The size of the rockets corresponded with the ulceracin activity (Fig. 4), indicating that the antiserum was directed against ulceracin itself.

In gel diffusion, diphtheria antitoxin reacted with $C$. ulcerans toxin (which is identical with $C$. diphtheriae toxin) but not with ulceracin 378 and conversely anti-ulceracin serum reacted with ulceracin but not with the toxin. 


\section{DISCUSSION}

In a previous study an 18-fold purification of ulceracin 378 was achieved by ammonium sulphate precipitation, dialysis and chromatography on DEAE-cellulose. However, in this study much more effective purification (360-fold) was achieved by dialysis, ion-exchange chromatography on DEAE-cellulose and gel filtration on Sephadex G-200. The ion-exchange step not only purified the crude ulceracin but also concentrated it.

On the basis of Ultrogel AcA22 gel filtration, ulceracin was found to have a molecular weight of about 900000 . Because of its large molecular size untreated ulceracin did not enter the $5 \% \mathrm{gel}$ when subjected to PAGE. However, when purified ulceracin was treated with 2mercaptoethanol and subjected to SDS-PAGE purified ulceracin migrated as five bands. Two major bands migrated ahead of the other three and stained heavily for protein but not for carbohydrate or lipid. Ulceracin activity was associated with the major band 4 (Fig. 3). Band 5 represents C. ulcerans 378 toxin (Abrehem \& Zamiri, 1980). Comparison of the relative mobility of the major active band 4 with the mobility of the marker proteins indicated a molecular weight of 25000 , suggesting that in the native state ulceracin is composed of aggregates of identical subunits. On the basis of these findings, ulceracin 378 can exist in two distinct molecular states, a dissociated form with a molecular weight of 25000 , and an aggregated form with a molecular weight of 900000 . Comparison of the relative mobility of the three minor protein bands with the mobility of known molecular weight proteins indicated molecular weights of 76000,66000 and 37000 respectively. However, under the conditions used bands 1, 2, 3 and 5 (Fig. 3) did not show bacteriocin activity. Ulceracin preparation after gel filtration through Sephadex G-200 followed by electrophoresis contained multiple bands, one of which (band 4) showed biological activity (Fig. 3).

Although crude ulceracin lost its activity after freeze-drying, highly purified ulceracin 378 retained its activity if freeze-dried in the presence of $1 \mathrm{mg}$ bovine serum albumin $\mathrm{ml}^{-1}$. Similar results were found in studies on colicin E2 (Mitusi \& Mizuno, 1969) and staphylococcin 1580 (Jetten \& Vogels, 1972). Partially purified ulceracin retained full activity within a wide range of $\mathrm{pH}$ values. It was also shown to be stable at $65^{\circ} \mathrm{C}$ for more than $2 \mathrm{~h}$.

The granular appearance of ulceracin 378 seen by electron microscopy resembles that reported for staphylococcin A-1262 (Lachowicz \& Kwaitkowski, 1972), staphylococcin 414 (Gagliano \& Hinsdill, 1970), Lactobacillus fermenti bacteriocin (de Klerk \& Smit, 1967), and Proteus morganii bacteriocin (Smit et al., 1968). None of the micrographs revealed any structure that resembled bacteriophage or its fragments.

On rocket electrophoresis the size of the rockets corresponded with the ulceracin activity indicating that the antiserum is directed against ulceracin itself. Further, a 1/32 dilution of the antiserum neutralized the biological action of ulceracin. Lack of antigenic cross-reactivity between purified ulceracin and purified toxin (isolated and purified from one producer strain) confirms that these two entities are distinct from each other.

\section{REFERENCES}

Abrehem, K. \& ZAMiri, 1. (1980). Purification of a protein toxin from Corynebacterium ulcerans no. 378. Journal of Medical Microbiology 13, 587--592.

Abrehem, K. \& ZAmiRI, I. (1983). Production of a bacteriocin (ulceracin 378) by Corynebacterium ulcerans. Antimicrobial Agents and Chemotherapy 24, 262-267.

Crowle, A. J. (1961). Immunodiffusion, pp. 304-310. New York: Academic Press.

Gagliano, V. J. \& Hinsdill, R. D. (1970). Characterization of a Staphylococcus aureus bacteriocin. Journal of Bacteriology 104, 117-125.

Jetten, A. M. \& Vogels, G. D. (1972). Nature and properties of a Staphylococcus epidermidis bacteriocin. Journal of Bacteriology 112, 243-250.

Jetten, A. M., DE WINDT, F. \& Vogels, G. D. (1972).
Production of a Staphylococcus epidermidis bacteriocin. Journal of Bacteriology 112, 235-242.

K LeRK, H. C. DE \& SMIT, J. A. (1967). Properties of a Lactobacillus fermenti bacteriocin. Journal of General Microbiology 48, 309-316.

LACHOWICZ, T. \& KWAITKOWSKi, B. (1972). A structural analysis of staphylococcus $A$ in the electron microscope. Folia histochemica et cytochemica 10, 257-264.

Laurell, C. B. (1972). Electroimmunoassay. Scandinatian Journal of Clinical and Laboratory Investigation 29. Supplement 124, 21-37.

Mitusi, E. \& Mizuno, D. (1969). Stabilization of colicin E2 by bovine serum albumin. Journal of Bacteriology 100, 1136-1137.

Sargent, R. J. \& George, S. G. (1975). Methods in 
Zone Electrophoresis, 3rd edn, p. 109. Poole, UK : BDH Chemical.

Smit, J. A., De KleRK, H. C. \& Coetzee, J. N. (1968). Properties of a Proteus morganii bacteriocin. Journal of General Microbiology 54, 67-75.
WEBER, K. \& OSBORN, M. (1969). The reliability of molecular weight determination by dodecyl sulphate polyacrylamide gel electrophoresis. Journal of Biological Chemistry 244, 4406-4412. 